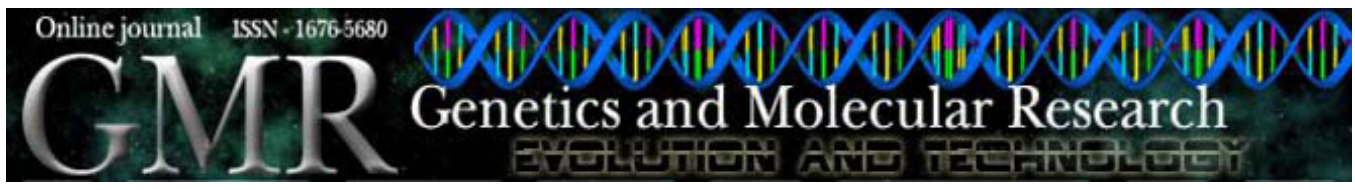

\title{
Cost-effective analysis of genotyping using oral cells in the geriatric population
}

\author{
T. Juárez-Cedillo ${ }^{1}$, S. Sánchez-García ${ }^{1}$, J.F. Mould-Quevedo ${ }^{2}$, \\ C. García-Peña ${ }^{1}$, J.J. Gallo ${ }^{3}$, F.A. Wagner ${ }^{4}$ and G. Vargas-Alarcón ${ }^{5}$ \\ ${ }^{1}$ Epidemiologic and Health Service Research Unit, Aging Area, \\ Mexican Institute of Social Security, Mexico City, Mexico \\ ${ }^{2}$ Health Economic Research Unit, Mexican Institute of Social Security, \\ Mexico City, Mexico \\ ${ }^{3}$ Department of Family Practice and Community Medicine, \\ University of Pennsylvania, Philadelphia, PA, USA \\ ${ }^{4}$ School of Public Health and Policy, Department of Public Health Analysis, \\ Drug Abuse Research Program, Morgan State University, \\ Baltimore, MD, USA \\ ${ }^{5}$ Department of Molecular Biology and Cardiovascular Diseases, \\ Genomic and Proteomic Study Group, \\ National Institute of Cardiology Ignacio Chávez, Mexico City, Mexico
}

Corresponding author: G. Vargas-Alarcón

E-mail: gvargas63@yahoo.com

Genet. Mol. Res. 9 (3): 1886-1895 (2010)

Received May 28, 2010

Accepted July 16, 2010

Published September 21, 2010

DOI 10.4238/vo19-3gmr939

ABSTRACT. We evaluated the cost-effectiveness of using buccal swab brushes in comparison with blood samples for obtaining DNA for large epidemiological studies of the elderly population. The data reported here are from the third phase of the Integral Study of Depression among the Elderly in Mexico City's Mexican Institute of Social Security, conducted in 2007. The total cost of the two procedures was determined. The measurement of effectiveness was the quality and quantity of DNA measured in $n g / \mu \mathrm{L}$ and the use of this DNA for the determination of apolipoprotein $E(A P O E)$ polymorphism by PCR. Similar rates of amplification were obtained with the two techniques. The cost of the buccal swab brushes, including sample collection and DNA extraction, 
was US\$16.63, compared to the cost per blood sample of US\$23.35. Using the buccal swab, the savings was US\$6.72 per patient $(\mathrm{P}<0.05)$. The effectiveness was similar. Quantity and quality of DNA obtained were similar for the oral and blood procedures, demonstrating that the swab brush technique offers a feasible alternative for large-scale epidemiological studies.

Key words: Buccal swab brushes; DNA extraction; Elderly; Epidemiologic studies

\section{INTRODUCTION}

Many epidemiological studies have focused on genetic factor associations as possible determinants of the diseases of aging, such as dementia, depression and osteoporosis. Historically, DNA has been obtained from venous blood (London et al., 2001). Even though this method provides a substantial amount of DNA, there are some risks related to the extraction process, such as the risk of exposure to blood pathogens and the handling of liquid samples (Richards et al., 1993). In addition, the procedure may not be suitable in certain vulnerable populations for various logistic and/or cultural reasons, and the refusal rate is higher. Even when the procedure is feasible, cost can be an obstacle (Harty et al., 2000; Le Marchand et al., 2001). As a consequence, the validity of results in epidemiological studies may be compromised.

Recently, it was shown that epithelial cells are in a constant process of exfoliation and can be captured through a simple non-invasive procedure to obtain DNA (Le Marchand et al., 2001; Gavriel et al., 2005). Several methods for collecting cells have been reported in the literature, which can be divided into wet procedures that involve mouthwashes, and dry procedures based on buccal swab brushes. There are advantages and disadvantages for each type. Wet procedures seem to have less bacterial contamination and yield better quantities of DNA. However, this type of procedure requires much more handling during sample processing (Heath et al., 2001). Dry procedures are very simple. The samples are very easy to transport and they can be stored until processing (Feigelson et al., 2001), but both the quantity and quality of DNA, as shown by the polymerase chain reaction (PCR), are variable (GarcíaClosas et al., 2001). These procedures are particularly useful in fieldwork when highly trained personnel, equipment or special facilities are not available, or if there are reasons for not taking blood samples (Cozier et al., 2004). However, there are no epidemiological studies where this method has been applied in large samples of the elderly population, at home rather than in medical facilities.

Consequently, the purpose of this study was to determine the cost-effectiveness of the buccal swab brushes for collecting and obtaining high-quality DNA in participants 60 years and older compared with the usual invasive procedure. The utility of cytobrushes was tested through the amplification of the apolipoprotein $E$ ( $A P O E$ ) gene by PCR. The results of this study were used to standardize the oral sampling method and to analyze the relationship between $A P O E$ polymorphisms and depression and cognitive impairment in a cohort study that recruited 2350 participants who were older than 60 years, residents of Mexico City and insured by the Instituto Mexicano del Seguro Social (IMSS). 


\section{MATERIAL AND METHODS}

\section{Patients and controls}

The data reported here are from the third wave of the Integral Study of Depression among the Elderly, conducted in 2007, among Mexico City's IMSS policyholders (GarcíaPeña et al., 2008).

\section{Sample collection with buccal swab brushes and subsequent processing}

The participants were visited and interviewed at their home after written informed consent was obtained by staff trained in the process of sampling. The participants were instructed to rinse their mouth before the sample collection, and afterward, the interviewer scraped the right cheek with a sterile MasterAmp ${ }^{\mathrm{TM}}$ Buccal Swab Brush (Epicentre Technologies ${ }^{\circledR}$, WI, USA) number one and the left cheek with the buccal swab brush number two, moving the brush up and down, exerting pressure against the tissue but without touching the teeth. Afterward, these brushes were returned to the hard-pack cylinder and labeled with the date and time of the sampling. Brushes were stored during the working day in a cooler with a temperature of $4^{\circ} \mathrm{C}$. At the end of the day, samples were transported to the genetics laboratory and were kept in a freezer at $-70^{\circ} \mathrm{C}$ for up to $72 \mathrm{~h}$ before processing. The elapse of time was recorded to determine the effect of time and temperature on the performance and quality of DNA.

The DNA material from each of the brushes was placed in a $1.5-\mathrm{mL}$ microcentrifuge tube. Next, $600 \mu \mathrm{L} 50 \mathrm{mM} \mathrm{NaOH}$ was added, and the tube vortexed for $1 \mathrm{~min}$ and heated to $95^{\circ} \mathrm{C}$ for $5 \mathrm{~min}$; it was found to be important that there was no temperature variation at this point. After the warming-up and with the brush still inside the tube, $120 \mu \mathrm{L} 10 \mathrm{mM}$ Tris-HCl, $\mathrm{pH} 8$, was added to each tube. The brush was then taken out and then shaken. The extracted DNA was stored at $4^{\circ} \mathrm{C}$. Subsequently, each sample was electrophoresed on a $0.9 \%$ agarose gel, and stained with $0.4 \mu \mathrm{g}$ ethidium bromide to verify the integrity of the sample, and a high molecular weight was observed in each DNA sample. Finally, DNA purity was verified by capillary spectrophotometry using a NanoDrop ${ }^{\circledR}$ ND-1000 UV-Vis apparatus (Perkin Elmer, Lambda Bio, MA, USA), and the DNA concentration was quantified by comparison with human DNA standards.

The integrity of genomic DNA was assessed by resolving DNA extracts by electrophoresis on a $0.4 \%$ agarose gel, followed by visualization with ethidium bromide staining. Each DNA sample was evaluated according to the electrophoresis migration of the sample in comparison to a known molecular weight marker (Ready-Load 1 DNA/HindIII Fragments; Life Technologies, Inc., CA, USA).

\section{Detection of $A P O E$ genotypes}

Two PCR amplicons encompassing either the apoE codon 112 or 158 were generated from genomic DNA (extracted from the buccal swab brush and blood samples) either with the codon 112 forward primer, 5'-biotin-GGCGCGGACATGGAGGAC-3', and the codon 112 reverse primer, 5'-TGCACCTCGCCGCGGTAC-3', resulting in a 58-bp amplicon, or the codon 158 forward primer, 5'-biotin-GGCTCCTCCGCGATGCC-3', and the codon 158 reverse 
primer, 5'-CCCGGCCTGGTACACTGC-3', resulting in a 57-bp amplicon. PCR mixtures (50 $\mu \mathrm{L}$ ) were prepared by mixing $15 \mathrm{mM}$ Tris-HCl, $\mathrm{pH} 8.0,50 \mathrm{mM} \mathrm{KCl}$ (GeneAmp Gold buffer, PE Biosystems, USA), $2.5 \mathrm{mM} \mathrm{MgCl} 2,200 \mathrm{mM}$ each of dATP, dCTP, dGTP, and dTTP (A Biosystems, USA), $1 \mathrm{mM}$ forward primer, $1 \mathrm{mM}$ reverse primer, $1.25 \mathrm{U}(0.25 \mu \mathrm{L}$ of a $5 \mathrm{U} / \mu \mathrm{L})$ AmpliTaq Gold polymerase (PE Biosystems) and $100 \mathrm{ng}$ genomic DNA as template. After an initial 15 -min denaturation step at $95^{\circ} \mathrm{C}, 30$ cycles of PCR were carried out $\left(40 \mathrm{~s}\right.$ at $95^{\circ} \mathrm{C}, 40 \mathrm{~s}$ at $65^{\circ} \mathrm{C}$ and $40 \mathrm{~s}$ at $72^{\circ} \mathrm{C}$ ), followed by extension at $72^{\circ} \mathrm{C}$ for $10 \mathrm{~min}$. Purification of the PCR amplicons was not necessary (Emi et al., 1988).

For genotyping, two TaqMan assays (Applied Biosystems, Foster City, CA, USA) were used. For the single-nucleotide polymorphism (SNP) in codon 112, primers were sense 5'-GCTGGGCGCGGACAT-3' and antisense 5'-CACCTCGCCGCGGTACT-3', and probes were 5'-CGGCCGCGCACGTCC-3' labeled with FAM and 5'-AGGCGGCCGCACACGTC-3' labeled with VIC. For the SNP in codon 158, an Assay-On-Demand (Applied Biosystems) was used (assay ID C_904973_10). The assays were run on a 7900HT (Applied Biosystems) according to manufacturer specifications, with the following modifications: a Eurogentec quantitative polymerase chain rection (qPCR) core kit (Eurogentec, Seraing, Belgium) was used according to standard specifications; half the concentrations of primers and probes were used; the number of PCR cycles was 50. Fluorescence intensities were measured after PCR, and genotypes were indicated by the Sequence Detection Software version 2.0 (Applied Biosystems).

\section{Blood cell collection and processing}

Participants were scheduled for blood collection at the Epidemiological Research Unit on Aging; an interviewer collected the written consent and administered the questionnaire, and a nurse performed the procedure. Genomic DNA was isolated from peripheral blood by a salting-out procedure (Miller et al., 1988).

\section{Cost of the sample collection and typing}

The measurement of effectiveness was determined by the amount and quality of DNA obtained with each technique, as well as the successful identification of the APO E polymorphisms, and costs were calculated based on the actual time spent/person, which included sample collection, transporting and processing, cost of equipment and laboratory material used in the typing of DNA by real-time PCR. Also, all stationery and cooler used were considered in the total costs. The study perspective was institutional, and therefore only direct medical costs were included in the analysis. The costs are expressed in US dollars according to the 2010 exchange rate officially reported by the Bank of México (1 US dollar $=13.047$ Mexican pesos).

\section{Statistical analysis}

An analysis to evaluate the yields of each sample was carried out to establish differences in the time when the sample was taken, using one-way analysis of variance (ANOVA). Subsequently, the DNA yield of both brushes was also evaluated by ANOVA. 
This analysis was made to identify compliance with the instructions of the sample-taking process. The amount of time during the sample taking, transportation temperature and storage was compared. Each parameter was adjusted for the time of the sampling and transportation temperature. The number of samples obtained with brushes and successful for $A P O E$ amplification was also evaluated using the Fisher exact test. For the cost-effectiveness analysis, the effectiveness measure was considered as the yields of DNA obtained from two buccal swab brushes versus the DNA obtained from the blood samples for each participant and the determination of the APO E polymorphism by PCR. The significance level was set at two-sided $\mathrm{P} \leq 0.05$ throughout.

The IMSS National Health Research Committee and Ethics Committee reviewed and approved the research protocol of which this study is a part (2001-785-015).

\section{RESULTS}

\section{DNA yields from samples with the collection methods}

Of the total sample $(\mathrm{N}=2362)$, the rate of participation was $93.39 \%$ (2206). It was possible to obtain results for PCR in $2179(98.8 \%)$. The refusal rate was $6.6 \%(\mathrm{~N}=156)$. The average age was $70.00 \pm 7.03$ and $66.9 \%$ were women.

Of the total, 2350 were invited to the research unit for the blood sampling, among whom $57.14 \%$ responded, resulting in 1342 samples.

The DNA yields were evaluated for both brushes. Figure 1 shows the DNA integrity measured on agarose gels. The presence of high-molecular weight DNA was observed in each of the implied lanes.

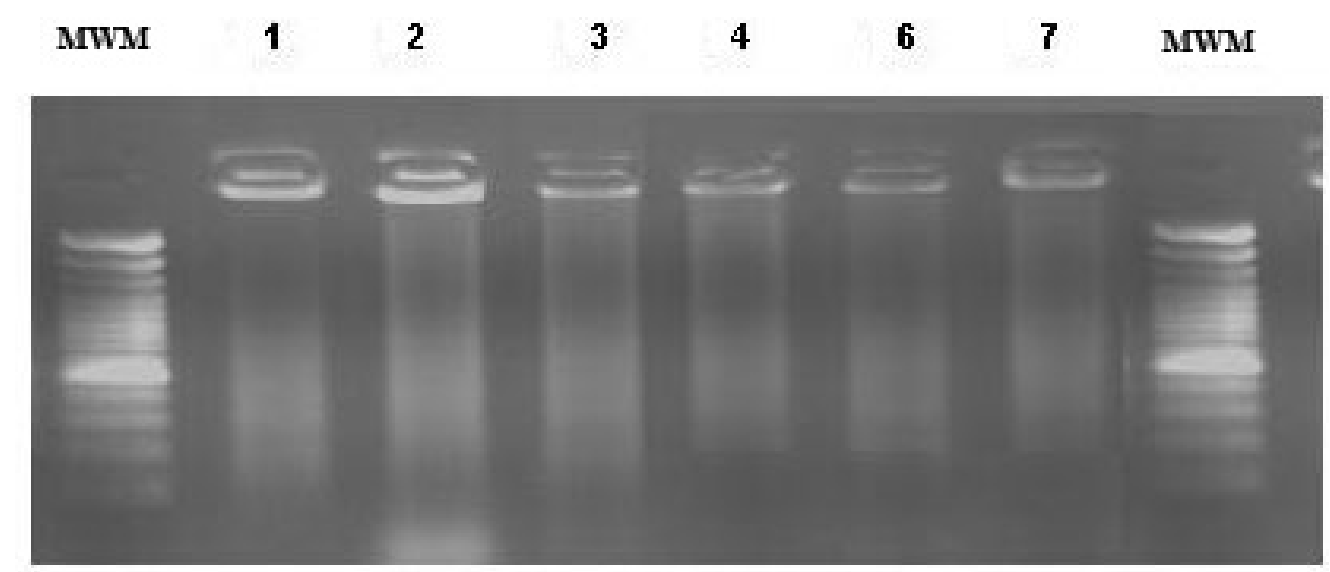

Figure 1. DNA integrity obtained with buccal brush. MWM = Molecular weight marker (HaeIII). Lanes 1-7 = DNA extracted from buccal swab brushes ( $5 \mu \mathrm{L}$ DNA with $5 \mu \mathrm{L}$ buffer).

DNA yield was variable (ranging from 17.50 to $918.58 \mathrm{ng} / \mu \mathrm{L}$ ) with an average of $226.33 \mathrm{ng} / \mu \mathrm{L}$, and $87.37 \%$ of the samples showed a concentration higher than $100 \mathrm{ng} / \mu \mathrm{L}$ (ranging from 100.03 to $918.58 \mathrm{ng} / \mu \mathrm{L}$ ) while only $12.62 \%$ showed a concentration lower than $99.73 \mathrm{ng} / \mu \mathrm{L}$ (Figure 2). 


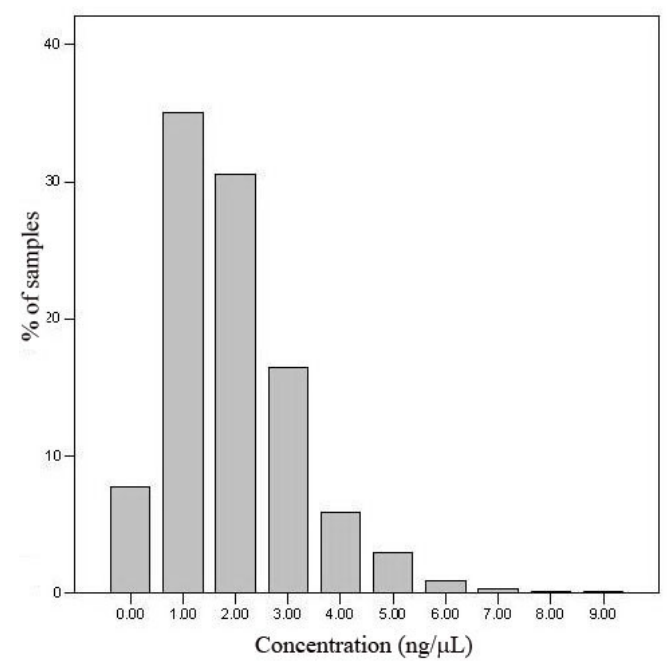

Figure 2. DNA yields (ng) by cytobrush where it was possible to obtain PCR results (2179 samples). The quantity of DNA extracted from each brush was determined by spectrophotometry using a blood sample as the standard.

DNA yield was influenced by the time elapsed from the taking of the sample to the moment that it arrived at the laboratory, with a gradual decrease from 5 to $25 \mathrm{ng} / \mu \mathrm{L}$ among the samples that were transported within the first $5 \mathrm{~h}$ after sample taking; however, for the samples after $7 \mathrm{~h}$, there was an observable increase of up to $8 \mathrm{ng} / \mu \mathrm{L}$. This same pattern was observed with the transportation temperature and storage time, as shown in Table 1. For the blood samples, the yield displays an average of 257.09 (ranging from 0.83 to $1694.31 \mathrm{ng} / \mu \mathrm{L}$ ).

\begin{tabular}{|c|c|c|c|c|c|}
\hline \multirow[t]{3}{*}{ DNA extraction } & \multirow[t]{3}{*}{$\mathrm{N}=2179$} & \multicolumn{4}{|c|}{ Spectrophotometry } \\
\hline & & \multicolumn{2}{|c|}{ Total yields of DNA $(\mathrm{ng} / \mu \mathrm{L})$} & \multicolumn{2}{|c|}{$\mathrm{A} 260 / \mathrm{A} 280 \mathrm{~nm}$} \\
\hline & & Median & Range & Median & Range \\
\hline \multicolumn{6}{|c|}{ Time for transport to the laboratory (h) } \\
\hline $0-2$ & 599 & 245.25 & $36.13-822.72$ & 1.49 & $0.89-1.75$ \\
\hline $3-4$ & 1049 & 220.35 & $17.50-918.58$ & 1.48 & $0.91-1.70$ \\
\hline $5-6$ & 519 & 216.19 & $39.89-711.83$ & 1.50 & $1.01-1.74$ \\
\hline More than 7 & 12 & 224.31 & $89.48-645.22$ & 1.45 & $1.24-1.60$ \\
\hline \multicolumn{6}{|c|}{ Temperature during transportation } \\
\hline $4^{\circ} \mathrm{C}$ & 1926 & 227.49 & $17.50-918.58$ & 1.48 & $0.89-1.75$ \\
\hline$>4^{\circ} \mathrm{C}$ & 253 & 216.61 & $47.05-729.28$ & 1.51 & $1.01-1.74$ \\
\hline \multicolumn{6}{|l|}{ Time of storage (h) } \\
\hline 24 & 1691 & 227.26 & $17.50-918.58$ & 1.48 & $0.89-1.71$ \\
\hline 72 & 488 & 222.66 & $36.13-841.26$ & 1.50 & $1.05-1.75$ \\
\hline
\end{tabular}

\section{PCR amplification results with each collection method}

The quality of the DNA was evaluated by determination of $A P O E$ polymorphisms using conventional PCR plus restriction analysis. The amplification produced two fragments of 57 and $58 \mathrm{bp}$ for each assay, obtaining similar rates of amplification. Of the $289(13.1 \%)$ samples with a DNA concentration lower than $100 \mathrm{ng} / \mu \mathrm{L}$, only in $6(2.1 \%)$ was it impossible to obtain results. Similar results were observed in those samples in which the concentration 
was $401-500 \mathrm{ng} / \mu \mathrm{L}$, where the success percentage was $2.5 \%$. This fact can be explained by the time that had passed from the taking of the sample to the arrival at the laboratory (more than $4 \mathrm{~h}$ ). However, in spite of the fact that $48.8 \%$ of the samples showed a concentration of 17.50 $300 \mathrm{ng} / \mu \mathrm{L}$ and $44.0 \%$ had a concentration of $301-918.58 \mathrm{ng} / \mu \mathrm{L}$, there were no significant differences in the amplification success rate. This indicates that the DNA obtained from oral cells does not exhibit degradation ( $\mathrm{P}>0.05)$. For the blood samples, $17 \%(34)$ had a concentration lower than $100 \mathrm{ng} / \mu \mathrm{L}$, and only in $2(11.7 \%)$ was it impossible to obtain PCR results. From the results presented here, we conclude that no difference in effectiveness was found, and therefore, we report a cost minimization analysis (Table 2). This analysis is focused on showing which alternative would be the most cost-effective, yielding lower costs (institutional savings) between the two options, since their effectiveness is statistically the same.

Table 2. Yields and quality of DNA measured by UV and the success rate in polymerase chain reaction (PCR).

\begin{tabular}{|c|c|c|c|c|c|c|c|}
\hline \multirow[t]{2}{*}{ Method of collection } & \multirow[t]{2}{*}{$\mathrm{N}$} & \multicolumn{3}{|c|}{$\mu \mathrm{g} \mathrm{DNA}^{\mathrm{a}}$} & \multicolumn{2}{|c|}{ A260:A280 } & \multirow{2}{*}{$\begin{array}{l}\text { Rate of success in } \\
\text { PCR }(A P O E)\end{array}$} \\
\hline & & Mean \pm SD & $\mathrm{P}$ & Range & Mean \pm SD & Range & \\
\hline Buccal swab brush & 2179 & $226.33 \pm 121.93$ & & $17.50-918.58$ & $1.49 \pm 0.14$ & $0.89-1.75$ & 98.77 \\
\hline Blood & 1342 & $257.09 \pm 314.63$ & $<0$. & $0.83-1694.31$ & $1.84 \pm 0.190$ & $0.89-2.55$ & 99.0 \\
\hline
\end{tabular}

$\mathrm{A}=$ absorbance. $\mathrm{a}=$ total DNA obtained from two brushes per individual.

\section{Cost minimization analysis}

The total cost of the buccal swab brush technique for the 2179 samples was US\$36,241.89 (US\$7,816.14 for sampling, US\$7,187.12 for DNA extraction, US\$12,883.47 for DNA amplification, and US\$4,216.45 for genotyping) and US\$4,138.69 for equipment. On the other hand, the total costs of blood samples for 2179 samples resulted in US\$50,897.64, which includes US\$15,632.25 for sample taking, US\$13,477.56 for DNA extraction, US\$12,883.47 for DNA amplification, and US\$4,216.45 for genotyping, and a total of US\$4,687.91 for equipment (Table 3).

\begin{tabular}{lccc}
\multicolumn{4}{l}{ Table 3. Total costs of buccal swab brush and blood sampling techniques. } \\
\hline Procedure & Buccal swab brush & Blood samples & Difference \\
\hline Sample taking & $7,816.14$ & $15,632.25$ & $7,816.11$ \\
DNA extraction & $7,187.12$ & $13,477.56$ & $6,290.43$ \\
DNA amplification & $12,883.47$ & $12,883.47$ & 0 \\
APO E determination & $4,216.45$ & $4,216.45$ & 0 \\
Equipment & $4,138.69$ & $4,687.91$ & 549.21 \\
Total & $36,241.89$ & $50,897.64$ & $14,655.75$ \\
Total cost per sample & 16.63 & 23.35 & 6.72 \\
\hline
\end{tabular}

Total cost, based on 2179 samples obtained by buccal swab brush and blood samples. Calculated based on market prices for the year 2010 in US dollars (US\$).

The results mentioned above yielded a cost per sample of US\$14.73 for the buccal swab brush, without taking into consideration the investment in equipment that is required in other studies. If the equipment is included, total costs per sample resulted in US\$16.63, compared to the total costs per blood sample, which was US\$23.35. In this sense, the dry procedure saves US\$6.72 per sample $(\mathrm{P}<0.05)$. Therefore, it is possible to conclude that the procedure for obtaining oral cells using a buccal swab brush is a cost-saving strategy, which 
can achieve equal effectiveness.

\section{DISCUSSION}

There was no statistically significant difference in the condition of the DNA obtained from buccal cells collected from the brushes compared to the blood samples. Our results suggest that this technique is a good alternative for obtaining DNA of high quality in large-scale epidemiological studies involving vulnerable populations such as children or the elderly, in which the use of a mouthwash can be complicated since it can be easily swallowed by these subjects.

The DNA yields obtained in our study were higher than those reported in previous studies (García-Closas et al., 2001; Gavriel et al., 2005; Rylander-Rudqvist et al., 2006). In contrast with previous reports, during our sample collection process, the cytobrush was not allowed to come into contact with teeth, in order to reduce bacterial contamination. This is a major difference with the other studies, in which the results were significantly influenced by the presence of bacteria (Feigelson et al., 2001), since the previous studies indicated that a high quantity of the DNA obtained was the result of oral microbial contamination (Feigelson et al., 2001; Andrisin et al., 2002).

To minimize contamination with any remaining food and/or PCR inhibitors (e.g., lipstick), as well as bacterial proliferation, participants were requested to rinse their mouth with water prior to sampling. All samples were maintained at a low temperature $\left(4^{\circ} \mathrm{C}\right)$ until their arrival at the genetics laboratory, where they were processed to prevent bacterial replication and to ensure the integrity of DNA. Additionally, when the samples were received at the laboratory, they were stored at $-20^{\circ} \mathrm{C}$ and were processed within the subsequent $72 \mathrm{~h}$. Feigelson et al. (2001) showed that brushing of the teeth before collecting the sample using a rinse decreased the amount of DNA by up to $40 \%$, so in our study, the subjects were asked to only rinse their mouth with water.

Another reason why our DNA yields were higher than in other reports may be due to the fact that we used two brushes instead of only one. Close attention was also paid so that during DNA extraction variations in temperature were avoided (heating to $95^{\circ} \mathrm{C}$ for $5 \mathrm{~min}$ ) and the $\mathrm{pH}$ was adjusted to 7 in each sample with Tris (Hemminki et al., 2001).

With regard to the quality of the DNA measured by PCR, the fragments were large enough to replicate the polymorphism studied based on that observed on the agarose gels. Also, patterns of DNA degradation were not observed and the presence of high-molecular weight DNA was evident. However, we have to admit that the quality of the DNA was affected by the time of transportation to the laboratory (more than $7 \mathrm{~h}$ ), showing an increase in the concentration of DNA, suggesting bacterial growth. The time of transportation affects moisture, temperature and $\mathrm{pH}$, and allows the proliferation of microorganisms, which could be retained in the brush. This is a possible problem, so keeping the temperature controlled at $-4^{\circ} \mathrm{C}$ at the time of sampling and during transportation to the laboratory, and then storing it at $-20^{\circ} \mathrm{C}$, may be needed to guarantee the success of PCR amplification. In addition, the PCR technique does not require amplification of large amounts of DNA (1-3 ng) (Feigelson et al., 2001).

Another indicator of the quality and quantity of human DNA is the number of PCR that can be performed with the DNA obtained. Since each amplification requires only 1 to 3 ng DNA, the sample obtained from the two brushes provided sufficient quantity for 100- 
150 PCR cycles. In terms of cost-effectiveness, it is possible to reduce the cost per sample to approximately US\$6.72 if brushes are used. Considering that taking blood samples involves a certain degree of complexity and requires trained personal, and that it also may have adverse effects such as unnecessary pain to the participant, besides posing a possible biological risk during handling and transportation, it is clearly evident that the collection of buccal cells with a cytobrush is a very good alternative, especially for large epidemiological studies (King et al., 2002).

The objective of this study was to determine the cost-effectiveness of brushes compared to blood samples for obtaining DNA. Unexpectedly, the effectiveness of the two methods was similar in terms of the quantity and quality of the DNA obtained, where there was no statistical difference found between them. An analysis of the minimization of costs was performed, according to the statements established for health technology assessment guidelines (Drummond and Sculpher, 2005). Therefore, our research shows not only the effectiveness of a new alternative to obtain DNA, but also the significant economic savings which may be achieved, a very important issue in settings with limited resources such as the Mexican Public Healthcare Institutions. This is the first economic evaluation performed in a developing country that has compared the interventions mentioned. Another interesting contribution is the redefinition of the procedures for obtaining a good yield of DNA and the details of a better method of extraction. Two points are basic. First, it is critical that the brushes not come into contact with teeth. Second, since the environmental temperature promotes bacterial overgrowth and the degradation of DNA, diminishing the likelihood of success, controlling temperature is crucial. In conclusion, high yields of DNA from buccal cells were obtained similar to those obtained with the more conventional and costly method of blood sampling.

\section{ACKNOWLEDGMENTS}

Research supported by grants from CONACyT (México, 2002-CO1-6868), Mexican Institute of Social Security (IMSS, 2002-382), and NIH-FIRCA R03 TW005888. F.A. Wagner was funded through grant DA 17796 from the National Institute on Drug Abuse and P60MD002217 from the National Center on Minority Health and Health Disparities.

\section{REFERENCES}

Andrisin TE, Humma LM and Johnson JA (2002). Collection of genomic DNA by the noninvasive mouthwash method for use in pharmacogenetic studies. Pharmacotherapy 22: 954-960.

Cozier YC, Palmer JR and Rosenberg L (2004). Comparison of methods for collection of DNA samples by mail in the Black Women's Health Study. Ann. Epidemiol. 14: 117-122.

Drummond M and Sculpher M (2005). Common methodological flaws in economic evaluations. Med. Care 43: 5-14.

Emi M, Wu LL, Robertson MA, Myers RL, et al. (1988). Genotyping and sequence analysis of apolipoprotein E isoforms. Genomics 3: 373-379.

Feigelson HS, Rodriguez C, Robertson AS, Jacobs EJ, et al. (2001). Determinants of DNA yield and quality from buccal cell samples collected with mouthwash. Cancer Epidemiol. Biomarkers Prev. 10: 1005-1008.

García-Closas M, Egan KM, Abruzzo J, Newcomb PA, et al. (2001). Collection of genomic DNA from adults in epidemiological studies by buccal cytobrush and mouthwash. Cancer Epidemiol. Biomarkers Prev. 10: 687-696.

García-Peña C, Wagner FA, Sanchez-Garcia S, Juarez-Cedillo T, et al. (2008). Depressive symptoms among older adults in Mexico City. J. Gen. Intern. Med. 23: 1973-1980.

Gavriel G, Modi N, Stanier P and Moore GE (2005). Neonatal buccal cell collection for DNA analysis. Arch. Dis. Child Fetal Neonatal Ed. 90: F187. 
Harty LC, Shields PG, Winn DM, Caporaso NE, et al. (2000). Self-collection of oral epithelial cell DNA under instruction from epidemiologic interviewers. Am. J. Epidemiol. 151: 199-205.

Heath EM, Morken NW, Campbell KA, Tkach D, et al. (2001). Use of buccal cells collected in mouthwash as a source of DNA for clinical testing. Arch. Pathol. Lab. Med. 125: 127-133.

Hemminki K, Xu G, Angelini S, Snellman E, et al. (2001). XPD exon 10 and 23 polymorphisms and DNA repair in human skin in situ. Carcinogenesis 22: 1185-1188.

King IB, Satia-Abouta J, Thornquist MD, Bigler J, et al. (2002). Buccal cell DNA yield, quality, and collection costs: comparison of methods for large-scale studies. Cancer Epidemiol. Biomarkers Prev. 11: 1130-1133.

Le Marchand L, Lum-Jones A, Saltzman B, Visaya V, et al. (2001). Feasibility of collecting buccal cell DNA by mail in a cohort study. Cancer Epidemiol. Biomarkers Prev. 10: 701-703.

London SJ, Xia J, Lehman TA, Yang JH, et al. (2001). Collection of buccal cell DNA in seventh-grade children using water and a toothbrush. Cancer Epidemiol. Biomarkers Prev. 10: 1227-1230.

Miller SA, Dykes DD and Polesky HF (1988). A simple salting out procedure for extracting DNA from human nucleated cells. Nucleic Acids Res. 16: 1215.

Richards B, Skoletsky J, Shuber AP, Balfour R, et al. (1993). Multiplex PCR amplification from the CFTR gene using DNA prepared from buccal brushes/swabs. Hum. Mol. Genet. 2: 159-163.

Rylander-Rudqvist T, Hakansson N, Tybring G and Wolk A (2006). Quality and quantity of saliva DNA obtained from the self-administrated oragene method - a pilot study on the cohort of Swedish men. Cancer Epidemiol. Biomarkers Prev. 15: 1742-1745. 